\title{
Fixed Expressions with Sacred Numerals (on the Basis of Kazakh and English Languages)
}

\author{
Shara Mazhitayeva ${ }^{1}$, Aigul Asanovna Abdrazakova ${ }^{1}$, Nurgul Asanovna Abdrazakova ${ }^{2}$, Zhanar Aldanyshkyzy \\ Kaskataeva $^{1} \&$ Turmahanbet Toleshovich Primbetov ${ }^{1}$ \\ ${ }^{1}$ Karaganda State University named after E.A. Buketov, Kazakhstan \\ ${ }^{2}$ Kazakh National Medical University named after C.D. Asphendijarova, Kazakhstan \\ Correspondence: Shara Mazhitayeva, Karaganda State University named after E.A. Buketov, Mukanov street, \\ 1-8, Karaganda 100026, Kazakhstan. E-mail: S_mazhit@mail.ru; sh-mazhit@inbox.ru
}

Received: August 4, 2014 Accepted: October 10, 2014 Online Published: December 2, 2014

doi:10.5539/ass.v11n1p219 URL: http://dx.doi.org/10.5539/ass.v11n1p219

\begin{abstract}
The numerals are specified by their symbolic meanings along with digital ones. One can find them mostly in fixed expressions, legend stories, zhyr-dastans. The article is devoted to the use of the sacred numbers in fixed expressions. The names of the numerals frequently appear in phraseological units, fixed expressions in Kazakh and English languages relating to religious beliefs, customs and traditions have been collecting from the early times depict all specific features of wealthy sentience and considered to be a word-hoard. The actual materials were collected from phraseological dictionaries of Kazakh, Russian and English languages. And also examples were taken from art works. There are different numerals used in phraseologisms and proverbs (two, four, five, six, eight, fifty, hundred, thousand and so on). The authors define a series of numbers which are considered to be sacred ones according some concept beliefs. In article are determined the peculiarities of using numbers three, seven, nine, thirteen, twenty five, forty, fifty in fixed expressions and the use of these numbers in different meaning, to possess the sacred name.
\end{abstract}

Keywords: sacred numerals, languages relating, language and nation, customs and traditions

\section{Introducion}

The well-known scholars such as M. Kashkary, A. Navoyee, W. Humboldt, L. Vicegerber, and etc. devoted a lot of their works to the interrelation and correlation between language and culture, language and nation, the specific way of thinking that differs from other nations.

"Lexis is like a mirror in language, through it to know the past life of nation" (Wilfred Funk, 1950), wrote American scholar Wilfred Funk.

"Language history and culture history is closely related and reflect each other in some way" (Palmer, 1983), wrote L.R. Palmer.

Different semantically groups and layers that exist in General Lexicology of Kazakh language were carefully examined from the point of their ethnolinguistic value by academician A. Kaidar, E. Zhanpeyessov, M. Kopylenko, N. Uali, Zh. Mankeeyeva, A. Mukatayeva, K. Gabitkhanuly, N. Ongarbayeva and others.

Ethnolinguistic features of fixed expressions with sacred numerals still requires a care full study. Ethnolinguistics is a complex and difficult field of linguistics, which studies the way an ethnic group perceives the world, the way it is preserved in the community language through its history over centuries, that are better known as a cultural heritage transmitted from generation to generation and is constantly recreated in response to the environmental changes (Kopylenko, 1995 \& 2010; Krasnyh, 2008; Kaidarov, 2006).

\section{Materials and Methods}

The methods of this research are collecting, collation, analysis, research to determine the location of the sacred numbers in the field of education, training and understanding of the close relationship of human life, with the mystery of the origin of understanding of the world of numbers for ethno-linguistic research. 
Ethnographical accounts about the English people were initially found in the writing of the Greek astronomer and geographer, Pute as (traded back to IV century); Roman historian, Cornelius Tacitus (in his prominent monograph 'Almania'); and Cesar's writings as well.

Ethnolinguistic investigations held in contemporary English linguistics are mainly based on two directions. The first took the side and propound the idea of Wilhelm von Humboldt (Humboldt, 2008). They believed that this branch of science studies language and its inner form, the diversity of worldviews and phenomenal unity of language. The second are the followers of American scientists. According to them, the ethnolinguistics aims to study natural languages, language phenomena and their specific features; a particular worldview that brings changes in language itself.

\section{Results}

Connative meaning of the sacred numbers is rich due to a great number of collocations fixed in the language and Kazakh conception in the form of phraseologisms and proverbs.

Proverb is effective instrument for the transmission of culture, social morality, manners and ideas of a people. It is a short meaningful popular saying, expresses a truth of experience or an observation in a strikingly figurative language. Every country transmits its reality and experience through proverbs as a sample for future generation. It is known that proverbs in lexicology of Kazakh and English languages have been investigated in some way (Mazhitaeva \& Abdrazakova, 2012).

In both languages a wide range of numerals (two, four, five, six, eight, fifty, hundred, thousand and etc.) are commonly used in phraseological units and proverbs to form a 'human' concept.

For example: Between two stools one goes to the ground; first thrive, then wife: Once bitten twice shy; there are two sides to every question; fool at forty is a fool indeed; horse stumbles that has four legs; keep a thing seven years and you will find a use for it ; old men are twice children; rain before seven, fine at eleven; ninety per cent of inspiration is perspiration; a cat has nine lives; a stitch in time saves nine; two is company, but three is none; four eyes see more than two; first catch your hare.

Thereby in the world mindset of two countries the numerals have sacred meaning except cardinal, ordinal and collective ones (Uraksin, 1990).

As for the meanings of sacred numerals existing in different languages are various. The numeral considered the sacred in one language, in other language may define negative meaning. For example, The number thirteen is considered to be an unlucky number in some countries as England, German, Israel, there are no houses with the number thirteen or the thirteenth row in the cinema. The number six hundred and sixty six is also sometimes thought to be the number of Satan.

Frenchmen invented the term «14-guest» because they hate number thirteen.

If there are thirteen guests in the party, in this situation they take person into their party. There is no place with the number thirteen in airplane and the thirteenth room in hotel. In America Businessman does not plan to meet at 13.00 o'clock.

For muslims, including the Kazakhs Friday the thirteenth is really respected day. Friday is the best day of the week. It is also recommended that Muslims clean and wash themselves and make sure they smell nice when they attend Friday Prayers.

It is at this point that a person becomes a teenager. They say that «at the age of thirteen a teenager is mature enough to build a family».

We identified the importance of number fifteen, twenty five, thirty, forty in human life from collected literary examples.

Number four and seven are considered an unlucky number in Chinese. The word for "eight" sounds similar to the word which means "prosper" or "wealth" that is why this number brings luck.

For many centuries "seven" is lucky and sacred number for Kazakh people. It takes a special place in national conception, customs, traditions and mindset. For many countries all over the world the number 'seven' is sacred one (Kasymova, 2010).

The number "seven" is also considered sacred in the Holy Bible. It says God created earth - seven days; one seven-day week is a reminder of our creator; God blessed the seventh day, making it holy. The number "seven" is usually equated with the idea of perfection. 
In Kazakh language there are a lot of phraseologisms and proverbs, fixed expressions related with this number. For example: zheti ata - seven grandfathers; zheti zhyrt - seven nation; sheti zhargy - seven law; zheti kazyna seven richness; zheti kyn - seven days; zheti tyn - seven nights (word for word translations) and so on.

The most part of proverbs based and associated with number seven. For example: zhut zheti agaiyndy misfortune never comes alone (english equivalent); zheti ret olshep bir ret kes - second thought are best (english equivalent); aila altau, akyl zheteu - cunning is six, mind is seven (word for word translation) (Mazhitaeva \& Abdrazakova, 2012).

Table 1.

\begin{tabular}{cc}
\hline \multicolumn{2}{c}{ The use of number seven in Proverbs } \\
\hline English & Kazakh \\
\hline Rain before seven, fine before eleven & $\begin{array}{c}\text { Zhut zheti agaiyndy - misfortune never comes } \\
\text { alone (english equivalent); }\end{array}$ \\
$\begin{array}{cc}\text { Seven is company, and nine confusion. } \\
\text { Zheti ret olshep bir ret kes - second thought are } \\
\text { b fool can ask more questions in an hour than a equivalent); } \\
\text { wise man can answer in seven years. }\end{array}$ & $\begin{array}{c}\text { Aila altau, akyl zheteu - cunning is six, mind is } \\
\text { seven (word for word translation). }\end{array}$ \\
\hline
\end{tabular}

The number three is also considered a sacred numeral. According to B. Kanarbayev, a significant role of the number three can be explained in the following way: 'Our ancestors strongly believed that a woman from its birth is a God of the sun and the earth, a human and life on the earth appeared due to her. 'A Zher-Ana (a Mother-earth) is a mother of every existence' - a notion derived from the beginning of primitive communal system. A father is the sun. A mother is the earth. A human is their child.

Kazakh people from ancient times while estimating different items and phenomenon tried to define specific features and find similarities with other things; carefully examined them and the most memorable ones were depicted in the folklore. In the storage of ethnical knowledge they were found in the following proverbs: Ush kunnen son adam korge de ujrenedi - in three days a person gets used to the grave (word for word translation); ush tagannyn biri kisajsa, kalgandary kulajdy - one of three column bends, the rest of them fall dawn (word for word translation).

Table 2.

\begin{tabular}{cc}
\hline \multicolumn{2}{c}{ The use of number three in Proverbs } \\
\hline English & Kazakh \\
Third time lucky & $\begin{array}{c}\text { Ush kunnen con adam korge de urenedi - in three } \\
\text { days a person gets used to the grave (word for } \\
\text { word translation) }\end{array}$ \\
$\begin{array}{c}\text { Ush tagannyn biri kisaisa, kalgandary kulaidy- one } \\
\text { of three column bends, the rest of them fall dawn } \\
\text { (word for word translation). }\end{array}$ \\
\hline
\end{tabular}

According to some researches there a lot of fixed expression with the number "nine" in Kazakh language. It comes from the idea that is dated back to the ancient vulgar superstitions and traditions that the world consists of nine pieces or parts. For example: togyz aiyp tarty; togyz sakka zhugirtti; togyz kumalak; togyz turyp, toksan tolgandy and so on.

Toguz kumalak ("nine balls"), the most popular game dating back to ancient times, is considered as a national sport in modern Kazakhstan. According to current data it has a long lasting history about 4000 years (Issina, 2012).

Kazakh people believe that toguz (nine) - is a unity of mistakes and demerits. As for the sacred significance of the number nine (nine months and nine days) represents the period a woman carries her developing baby in the womb before birth. Three times three equals nine. Nomads believed that the number nine is a holy number that symbolizes the peak of existence and it is widely used in their traditions and customs. The homonym of the number is «a long life».

The number 'nine' has a high significance in the folk beliefs and mythology of Central Asian peoples. Nine is considered a good number in Chinese culture because it sounds the same as the word "longlasting" and its also 
sacred for Arabic countries and Persians except Altai people. K.Gabitkhanuly cites that Chinese people examined the sky by dividing it into nine pieces (Gabitkhanuly, 2006).

The next sacred number is forty. It takes a special role in the national folklore. There a great number of fixed expressions and proverbs with this number: «One among the forty people is the holy one» / they believed that guests coming to your house would bring luck/; a woman as a cat has forty souls - the girl has forty soul (word for word translation); «even if the battle lasts forty years the one who is destined to stay alive will return home» / an evil chance seldom comes alone (it has forty relatives); kyrsyk kyryk agaiyndy - misfortune has forty relatives (word for word translation); kyryk kisi bir zhak, kynyr kisi bir zhak - forty men are one side, the curve person is one side (word for word translation); kyryk zhylga dein bai men kedei teneser - rich and poor will be equal in forty years (word for word translation); kysga kyryk zhigit soilesedi, biri alady - girl talks with forty fellows, but she chooses one of them (word for word translation).

In the proverbs about cattle breeding the number "four" is popular one. For example: Tort ayagy ten zhorga, sudigerge syrinedi; tort tuliktin toresi tuye. Proverbs about friends and enemies: Dushpan kozi torteu - enemy has four eyes (word for word translation); tort tuliktin toresi tuie - the best and head of cattle is a camel (word for word translation); otirik ekeu, shyn torteu - lie is two, truth is four (word for word translation); bi ekeu bolsa, dau torteu - if judge is two, quarrel will be four (word for word translation); otirik pen shyndyktyn arasy tort eli, kozben korsen shyn, kulakpen estisen otirik - the difference of lie and truth is four if you see with eye is true, if you hear it is lie (word for word translation).

So, the number "four" symbolizes the "unity" and "concord". It is based on the belief the universe is made up of a combination of four eternal "elements" or "roots of all": earth, water, air, and fire.

In English proverbs one and two number are more frequently used than others. For example: One body - no body - zhalgyzdun uni shykpas ....; one rotten apple injures its neighbours - bir karyn maidy bir kumalak shiritedi; it is the first step that costs - bassy katty bolsa, ayagy tatty bolady; one is never too old to learn - okusyz bilim zhok, bilimsyz kunin zhok; one foot is better than two crutches - kanagat karyn toigyzar; one drop of poison spoils the whole tun of wine - bir karyn maidy bir kumalak shiritedi.

Proverbs with the number "two": A bird in the hand is worth two in the bush - aspandagy sunkardan koldagy turymtaj artyk; once bitten, twice shy - auzy kuygen urip ishedi; score twice before you cut once - zheti ret olshep bir ret kes; three women and a goose make a market - eki ayel bazar, ush ayel zharmenke; two heads are better then one - kenesip pishken ton kelte bolmas; custom is the second nature - aury kalsa da, adet kalmaydy (Kenesbaev, 2007).

\section{Discussion}

A.Kunin has pointed out, there are a great number of proverbs and sayings with one and two numerals in English language (Kunin, 1972).

If we consider history facts of the research there are some scientific works in both languages devoting to the subject raised above. But they fail to settle mind in concerning the nature of sacred numerals. According to S. Kenesbayev "three", "seven", "nine", "forty" are considered sacred in Kazakh language (Kenesbaev, 1997). However K. Gabytkhanuly, points out, "three", "seven", "nine", "forty", "twelve" numbers differ from other numerals in bearing additional meaning (Gabitkhanuly, 2006). He believes that this idea can be proved that these numbers applied in collocations, legends, customs and traditions and other world outlooks.

If we review the number of authors who have devoted their works to the linguistic nature of proverbs and their similarities or specific features, they are Baitursynov A., Kenesbayev S., Sarsenbayev R., Adambayev B., Kaidar A., Nuryshev S., Musabayev G., Gabdullin M., Turbayeva G. The next scientists explored the issue of proverbs using comparative approach: Nurmakhanov A., Mukysheva E., Donbayeva A., Begalykyzy D.

In English language the tradition of collecting national rich heritage trace back to ancient times. According to the research the first volume of a large collection of proverbs «Book of proverbs in the Testament» was published in the fifth century (Raidaut, 1997; The Oxford Dictionary of English Proverbs, 1992; Spears, 2007.). Such scholars as N. Barley, A. Dundes, A.Krickman, G. Milner, A. Taylor, G. L. Apperson, Linda and Rodger Flavelder extensively researched the fixed expressions and proverbs closely related with national existence and consciousness in English.

The researches devoting to the nature of fixed expressions in English closely connected with the name of A.V. Kunin (Kunin, 1989; Kunin, 1986). English proverbs are widely used in the sacred book Bible. As far as it was so popular in the community, the lines from Bible fitted into daily life, and word combination which were extracted from the book turned into fixed expressions. 
Proverbs are perceived as the most content-rich heritage, writers use them frequently to make their thoughts shorter and concrete and more literal. English proverbs were widely used as in Bible as in Shakespeare works. Thereby a number of scholars believe that "the golden age" of proverbs contemporary the time of Shakespeare (Birenbaum, 1966; Quine, 1997; Mackay, Botner, \& Gates, 1997).

Thus, we can assume that the origin of numeral component in phraseological units and proverbs of both languages derives from the diversity of symbolic meaning of numbers and its dominant influence to their development.

\section{Conclusion}

Kazakh language is very rich and wonderful language. A great variety of words in the language is what it makes unique. A general stock of words can be distinguished by its meaning and function in a sentence into special groups, better known as Speech Patterns. One of the Parts of Speech is Numerals.

Collocations and proverbs with numerals, including the origin of sacred numbers, their national coloring it is recognized to be the object of research.

The research materials have been collected from works of akyns, extracts from fictions, dictionary of phraseology, volumes of proverbs and put in to a system.

The proverbs, phraseologies, riddles with numerals, areas of employment and ethno-linguistic and other factors of their origin, the role of sacred numerals in the formation proverbs and phraseologies have been defined.

'Three', 'seven', 'nine' and 'forty' are the sacred numerals which ethnolinguistic features carefully studied in the article. The numbers within cardinal and ordinal connotations are widely employed in other meanings than any others. It can be easily noticed in examples taken from proverbs, literary works' extracts, and verse lines.

We found our research is very relevant due to the fact we studied thoroughly that non-relative countries having specific spiritual values brought through historical milestones were the representatives of different worldviews. In the process of writing the article we acquired much information about early outlooks, history and culture of our ancestors. The wide range of examples where numerals used in formation some new notions helped to reveal their peculiarities. If to sum up the overall research we can assume that a phenomenon of maintaining new qualities and sacred features dates back a long history of the language. Turkic countries are not the only nations which can be characterized by extensive usage of holy numbers in their culture.

This phenomenon is specific to any country, especially Turkic ones as it takes an important role in their language and culture as well. Sacred numbers were found to be a basis to a myriad of collocations bearing cultural heritage of the country.

Sacred numbers are known to be an integral part of the ethnic culture of Kazakh and English languages, their relation in social interaction depicted by special and 'traditional' numbers by rendering cumulative function.

Thus, every language has its numbers with their specific sacred meaning and quality. Whatever language is Kazakh, Russian or West countries, all of them are greatly interested in the analysis of their specific features and usage areas. They are able to employ phrases in reference to their aims and meanings. Every digit has its educating significance and special place. Every number in Kazakh language which is known to be sacred bears educative meaning in additional to its main function.

The mysterious significance of sacred numbers can be explained when one examines their nature to symbolize the core of the nation, philosophical outlook to the world surrounding, religious beliefs, material environment. Three, seven, nine and forty are believed to be sacred for Kazakh people.

Studying holy numbers in Kazakh and English languages one can acquire their symbolic meaning and develop them further. «Numbers fails to rule the world, but are of great important tool in ruling it», - a thinker, poet and writer Goethe once told. He strongly believed that there is a mystery hidden in numbers.

Summing up, collocations with sacred numbers in both Kazakh and English languages are known to be language units bearing connotative meaning that depict and reflect social life, worldviews, religious and non-religious beliefs, customs and traditions.

To sum up, we have found during our research that the levels of forming fixed expressions with numeral are different. Not all numbers are applied in the fixed expressions. The most widely used 'four', 'seven' 'nine', 'forty' numbers in proverbs and phraseological units have been defined.

An overwhelming majority of scientists believe that numbers three, seven, forty are sacred numerals, in our view the following numbers as thirteen, fifty, twenty-five, sixty must be included to the common list of holy numbers. 
We aim to reveal the sacred meaning of these numbers by analyzing language material in further investigations of this linguistic field.

\section{References}

Birenbaum Y. G. (1966). Imaginative comparative turnovers in modern English. Philological science («High School» Edition, pp. 131-139).

Gabitkhanuly, K. (2006). Kazakh mythology in language (p. 166). Almaty.

Humboldt, W. (2008). Selected works on linguistics (Trans. from German, p. 400). Moscow.

Issina, I. G. (2012). Stereotypes and national language picture of the world (p. 237). Monograph. Karaganda.

Kaidarov, A. (2006). Bases of Ethnolinguistics (p. 300). Almaty.

Kenesbaev, S. (1997). Concept connecting with «Seven», «three», «nine», «forty». Selected works. Almaty: Academy of Science of Kazakh Republic.

Kenesbaev, S. (2007). Phraseological dictionary of Kazakh language (p. 952). Almaty.

Kopylenko, M. M. (1995). Bases of Ethnolinguistics (p. 78). Almaty: Eurasia.

Krasnyh, B. B. (2008). Ethnopsycholinguistics and cultural linguistics (p. 284). Course of lectures. M.: ITDGK «Gnozis».

Kunin, A. V. (1986). Course of phraseology of modern English (p. 325). Moscow: High School.

Kunin, A. V. (1989). English phraseology (p. 200). Moscow: High School.

Kunin, A. V. (2001). English-Russian phraseobook (3rd ed., p. 512). Moscow: Russian language.

Kustovskaya, S. (1987). English proverbs and sayings (p. 345). Minsk: Visheishaya shkola Publishers.

Mackay, A., Botner, M. T., \& Gates, J. (1997). Dictionary of American idioms: 800 units/ formalization A. Lourie (p. 464). St. Petersburg: Lan.

Mazhitaeva, Sh., \& Abdrazakova, A. (2012). Ethnolinguistics character of sacred numbers. European Researcher, 11-3(35), 2028-2031.

Mazhitaeva, Sh., \& Abdrazakova, A. (2012). The peculiarities of using numerals in fixed expressions. Education and science without borders Journal, 3, 144-147. Karaganda, Republic of Kazakhstan and Prague, Czech Republic.

Palmer, L. R. (1983). An Introduction to Modern Linguistics (p. 122). Beijing, "Shan u" edition.

Quine, W. O. (1997). Natural kinds in naming, necessity and natural kinds (p. 237). Ithact. London.

Raidaut, R. (1997). The explanatory dictionary of English proverbs (p. 256). Lan.

Richard Spears. (2007). McGraw-Hill's Essential American Idioms Dictionary (2nd ed., p. 289). McGraw-Hill's.

The Oxford Dictionary of English Proverbs. (1992). (Ed.: F. P. Wilson). Oxford University Press.

Uraksin, Z. G. (1990). Comparative studying and etymologization of phraseological units in Turkic languages: Problems of etymology of Turkic languages (p. 385). Alma-Ata.

Wilfred Funk. (1950). Word Origins and Their Romantic Stories (p. 7).

Kasymova, S. (2009). National basis of proverbs with a component of numerals (p. 25). Dissertation submitted for the scholarly degree of "Candidate of philological Sciences". Almaty.

Kunin, A. B. (1972). Phraseology of modern English language (p. 287). Moscow: International relations.

Kopylenko, M. M., \& Popova, Z. D. (2010). Essays on the general phraseology (p. 192). Publishing house: Book house of "LIBROKOM".

\section{Copyrights}

Copyright for this article is retained by the author(s), with first publication rights granted to the journal.

This is an open-access article distributed under the terms and conditions of the Creative Commons Attribution license (http://creativecommons.org/licenses/by/3.0/). 